\title{
DEKONSTRUKSI DIRI SENDIRI DALAM PROSES \\ PENCIPTAAN KARYA SENI
}

Ign. Hening Swasono Ph

Institu Seni Indonesia Yogyakarta

\section{Abstract}

Self deconstruction is a means of breaking down the established art creation, representing individual identity and abandoning modern art or conventional art creation. It was applied in a work of art, whose forms were cracked wood constructed like paintings. In the new concept of art creation, self-deconstruction of Derrida and Nagajurna was applied. The deconstruction as a concept of creating and acting bravely to break down reality and imitating self creation was applied until the zero point. In other words, the emptiness is stability.

"All possible" is the concept of creation applied by the writer. The concept was realized by using used wood as a medium of expression of artistic moments. The installation was composed of several different media such as wood, plastic and iron. The concept also abandoned single medium (the modern view of art creation). This art creation used the integration of creation and recreation as well.

The creation technique applied was assemblage, collage, and knockdown system with shifting understanding, namely function replacement. The knock-down system in the installation was made based on the artist's will or on the art viewers, display areas and the surrounding. In the name of deconstruction, the writer believes that the created arts are multi-interpretable.

Key words: deconstruction, installation art and interpretatio

\section{A. Pendahuluan}

\section{Latar Belakang}

Dua puluh lima tahun lamanya saya bergelut dalam dunia penciptan Seni Lukis (Seni Rupa), semenjak saya temukan gaya "Retak" atau "Retak-retak" sebagai gaya pribadi "identitas" lukisan Hening Swasono. Saya bangun dan tanam tembok identitas yang kokoh semakin menjulang, di dalam tembok sudah banyak lahir karya-karya, baik karya lukisan atau seni rupa lainnya. Berbagai pameran tunggal atau kelompok, di dalam maupun di luar negeri sudah saya tapaki dan mengukir jam terbang yang tentunya membuahkan nama sekaligus materi Berbagai eksprerimen dan eksplorasi bentuk, warna, ruang, secara intens sudah saya jelajahi agar kebaruan (novelty) saya peroleh dari hasil ini. Adapun perolehan dan pengaruhnya masih belum memuaskan. Hal ini sejalan dengan tuntutan pribadi pelukis dan tuntutan akademik sebagai pengajar seni lukis FSR IS Yogyakarta memberikan contoh atau tindakan nyata dalam berkreasi, guna memotivasi dan memicu kreativitas mahasiswa. 
Pada waktu itu saya tidak memahami dan menyadari secara mendalam bahwa dekonstruksi, imajinasi dan kreativitas sebenarnya sudah saya aplikasikan kedalam karya "retak", yang oleh pengamat seni disebut sebagai lukisan non konvensional (dua dimensional).

Setelah melanjutkan studi di Program Pascasarjana ISI Yogyakarta wacana penciptaan seni lukis berkembang saling silang dari dunia "teks" (studi pustaka). Akhirnya saya terinspirasi oleh "Dekonstruksi" Derrida dan Nagarjuna dengan "jalan tengah"nya, juga pandangan yang lain seperti "integrasi” Capra, "Berpikir Lateral" De Bono, "Quantum Seni" Dwi Marianto dan lainnya sebagai sumber acuan dan sekaligus sarana provokasi untuk penciptaan seni saya.

Pemahaman tentang dekonstruksi selalu terkait dengan pembacaan atas sebuah teks (Critchtey,1992: 22), "persoalan pembacaan kritis" (Derrida, 1976 Ixxxix) dan kreatif, dari bahasa teks, ke dalam bahasa rupa, "diluluhkan menjadi konsep seni rupa yang kritis dan kreatif pula, bukan persoalan yang mudah. Pertama, sebelumnya saya harus memahami tentang dekonstruksi (pembongkaran) terlebih dahulu. Kedua, setelah itu untuk dapat memahami inti persoalan dekonstruksi, yang paling utama adalah diri sendiri terlebih dulu harus dibongkar, agar mendapatkan "kesepahaman" dalam mengungkapkan bahasa rupa kreatif, lain dari yang lain, serta belum pernah saya ungkapkan melalui karya-karya atau bahasa rupa sebelumnya.

Alasan mengapa diri sendiri harus didekonstruksi ialah mengacu pada Derrida dengan pemikiran dekonstruksi gandanya, yaitu terhadap paham asa usul dan terhadap aktivitas mimesis, dalam teks Mallarme berjudul Mimique. Apa yang terjadi dalam mimesis sebetulnya adalah dekonstruksi diri sendiri (self deconstruction). Adapun "mengimitasi sesuatu" yang terjadi sebetulnya adalah "mengimitasi imitasi", parodi yang sesungguhnya adalah "parodi atas parodi" (Kearney, 1994: 168).

Mengacu pula ke Nagarjuna dalam Mulamadhyamakakarika dari dasar pemikiran pandangan Buddhis "pembebasan" semua makhluk dari "penderitaan" oleh ketidaktahuan, yaitu pengertian keliru tentang "realitas". Realitas adalah arus yang bergerak tak berinti dan sifatnya tak permanen. Inti dari kenyataan adalah aunya ("kosong"), aunyata ("kekosongan"). Nagarjuna melakukan dekonstruksi terhadap "ketidaktahuan" yang berakar pada pandangan yang keliru, juga terutama berlaku terhadap aunyata. Dengan dekonstruksi ini maka aunyata itu sendiri pada akhirnya "kosong". Dari sini dapat dilihat bahwa dekonstruksi yang dikembangkan nagarjuna bersifat sangat radikal dekonstruksi yang mendekonstruksi dirinya sendiri (self deconstruction) yang dikenal dengan "jalan tengah" (Inada, 1970: 38).

Dua poin di atas dan dengan mengacu pandangan dua filsafat Barat dan Timur, saya dapat "memahami" lebih luas arti filosofi dekonstruksi, sebagai wacana pembanding. Dekonstruksi diri sendiri, yaitu melebur, mencair dan membongkar diri sendiri, artinya meniru dari tiruan diri sendiri, atas realitas diri hingga titik "nadir" yaitu nol (kosong). Membongkar (dekonstruksi) dan mengosongkan (aûnyatâ) dari seluruh pandangan dan pengertian, yang hakikatnya tidak memiliki inti yang permanen. Saya yakini bahwa pandangan dan pengertian tentang identitas lukisan "retak-retak" hingga akhir hayat tetaplah retak-retak sebagai cerminan pribadi saya (hidup matinya lukisan retak-retak tetap saya pertahankan, tak ada keberanian untuk membongkar sedikit pun, walau ke arah pembongkaran melalui eksplorasi/ eksperimentasi saya geluti terus menerus, alhasil tetap tak dapat memenuhi apa yang saya inginkan secara idealistik. Saya sadar pembongkaran itu masih pada kulit luarnya saja yaitu pada bentuk, garis, warna, ruang, tekstur dan lain-lain. Setelah dekonstruksi saya temukan dan pahami bahwa pembongkaran yang efektif berasal dari dalam diri sendiri "untuk mau mengubah "berani" dan "disadari" sepenuhnya, akan perubahan itu, sebagai "modal dasar" menuju yang "baru" di situlah ide-ide liar akan bermunculan yang selama ini terepresi oleh dogma identitas rasionalis.

Pola pandang tentang imajinasi kemudian didekonstruksi, karena imajinasi tak akan pernah mati dan dapat mengubah segala-galanya. Imajinasi dapat menghancurkan apa yang saya hasilkan selama ini yaitu (identitas "retakretak"). Imajinasi juga bisa membangun kembali/ mengkonstruksi sesuatu yang sama sekali lain dari imajinasi retak-retak dulu, dalam bahasa ungkap atau kreasi yang lain "kebaruan".

Kini saya percaya dan yakini, dengan daya imajinasi ada suatu kemungkinan-kemungkinan ruang kreatif, semakin saya dekati dan selami ruang itu akan membukakan ruang-ruang lain dengan segala kemungkinankemungkinan tak terbatas. Keterbukaan ruang-ruang itu bermunculan dan berkeliaranlah suatu tanda-tanda kebijaksanaan dan kemungkinan-kemungkinan tanda-tanda potensi/ energi untuk dipetik, dibawa keluar, dan dinyatakan jadi karya apa saja (Marianto, 2006)

Simbiosis dekonstruksi Derrida kaitannya dengan ide yang akan diwujudkan, mengacu pula pada pembaca ganda (double reading), satu sisi pembacaan tafsir dominan, sisi lain pembacaan kontradiksi tafsir dominan, akan menjadikan pembacaan yang lain (Critchley, 1992: 23). Artinya, pada satu sisi saya mewujudkan suatu karya seni dapat berdiri sendiri sebagai karya Seni Visual, pada sisi lain dalam mewujudkan suatu karya seni dengan menggabungkan karya seni visual tadi (karena karya-karya sangat beragam ekspresinya). Kontradiktif satu karya dengan karya yang lain, kemudian diredam dengan tatanan instalasi. Media karya-karya tersebut di atas menggunakan kayu-kayu bekas sebagai media atau element utama dan media pendukung dari logam, batu, plastik dan lain-lain. Teknik pembuatannya dengan jalan: merakit (assemblage), kayu-kayu, menempel 
(kolase) logam, batu, plastik dan lainnya, teknik penyusunannya (Automatism) mengalir begitu saja. Aksentuasi perwujudannya: mengukir (gerenda), melubangi (bor). Sedangkan finishing: natural, warna, wood stain. Wujud atau tampilan karyanya dimensional/ meruang. Karya ini kemudian didisplay dengan pertimbangan peletakan: out door dan in door (sehingga unsur-unsur ruang masuk sekaligus sebagai pendukung kehadiran karya).

Simbiosis dekonstruksi Nagarjuna dengan "jalan tengah" dengan oposisi ganda atau satu jenis dualisme. Dua jenis kebenaran bukanlah menyatakan tentang dua jenis realitas melainkan satu realitas yang dinyatakan dengan cara atau sudut pandang berbeda. Kedua jenis kebenaran tersebut saling melengkapi dan menyempurnakan. Tanpa menyandarkan diri pada praktek umum setiap hari (yakni kebenaran relatif), kebenaran absulut tidak dapat diungkapkan. Tanpa pendekatan terhadap kebenaran absulut, nirvana tidak dapat dicapai. Artinya bahasa ungkap media antara fine art dan visual art atau high-low art, saya tidak mensoal dikotomidikotomi itu, karena keduanya saling melengkapi (Rizki A. Zaelani, 2002: 77-91) saya mengambil "jalan tengah", kadang saya menyeberang (Beyond) atau menggabungkan (ini iya/ itu iya, ini tidak/ itu tidak).

Munculnya seni instalasi, seni performan dan kolase membuat seni lukis tidak lagi sebatas cat, kuas dan kanvas (seni rupa kontemporer) karena batasbatas seni lukis semakin kabur ketika ruang lingkupnya ditembusi oleh mediamedia ekspresi tersebut di atas, kini pelukis kembali memperhatikan "Aura kosmologi" membuat kembali belajar pada tradisi. (Awuy, 2002: 97).

Sejalan dengan pemikiran Rizky dan Awuy, saat ini ujud yang saya "representasikan" dalam karya-karya seni visual intalasi adalah mengacu pada "Aura kosmologi", "multi kultur" atau "multi etnik" sekaligus sebagai identitas subyek, kemampuan parole atau indigenous culture (Awuy, 2002: 97)

\section{Rumusan Masalah}

Banyak saya jumpai barang/ perabot yang sudah lama, bekas yang dibuang begitu saja, terutama kayu yang keropok-keropok, gerowong-growong, geripisgeripis dimakan rayap, retak-retak, belah-belah dimakan umur, atau logam (tembaga, kuningan, dan lain-lain) dimakan umur/ karaten. Barang/ perabot yang dulu pernah berjasa dalam kehidupan manusia, setelah rusak di buang begitu saja. Seperti lesung, lumpang, kendang, topeng, tamborin, almari, kursi, meja, dan lain sebagainya yang terbuat dari kayu, hanya dijadikan kayu untuk di bakar.

Walau kayu bekas di situ ada "daya" atau "Roh" yang "luar biasa", karena dulu dipilih oleh tukang dijadikan alat bantu terutama untuk kelangsungan hidup manusia baik secara guna atau estetikanya saat itu.

Bahan kayu mempunyai "elastisitas yang fleksibel" dan "hangat", hadirnya beriringan dan pasti digunakan disetiap kehidupan karena elastisitas dan fleksibel kehadirannya sangat berguna, dan macam jenis dan karakternya sangat variatif. Biasanya digunakan untuk keperluan konstruksi rumah, perabot, pengobatan, pusaka dan lain-lain.

Melihat persoalan tersebut di atas, saya pribadi bila mengamati kayu yang keropos, gerowong, geripis, pecah, belah-belah, retak-retak, baik berupa barang/ perabot, saya "terinspirasi" untuk "meng-alih-kan fungsi" sebagai media "ekspresi, rekreasi dan kreasi", dengan semangat revivalisasi (memberi daya "lebih" hidup) dan karya-karya seni visual/ instalasi sengaja saya hadirkan bebas, liar, brutal, seadanya (alami). Tempel sana, tempel sini, lubang sana lubang sini, sebebas interpretasi dan imajinasi penikmat, untuk berperan aktif mengandai-andai dalam dunia imajinasi yang subjektif.

\section{B. Kajian Sumber Penciptaan}

\section{Dekonstruksi Derrida dan Nagarjuna}

Dekonstruksi telah mengglobal dan merasuki berbagai bahasa. Kata yang lahir dalam lingkungan filsafat ini telah menerobos masuk ke berbagai wilayah keilmuan, mulai dari kajian sastra, arsitektur, teologi, politik, pendidikan, kritik musik dan film, hukum, sejarah hingga pada seni rupa.

Akar katanya, de' dan construire (bahasa Prancis kata bendanya : deconstruction), kiranya dekonstruksi mewakili sebuah hasrat dan cita-cita untuk membongkar bangunan yang sudah mapan, mecopot setiap bagian sebuah konstruksi.

Jika pemikiran "yang lain" merupakan kerinduan filsafat Barat akan pembaruan radikal, yang bisa menjadi semacam pembebasan, maka pemilihan Nagarjuna (sekitar abad ke $2 \mathrm{M}$ ), seorang pemikir dekonstruksi timur, sebagai pembanding Derrida kiranya bukan pilihan yang keliru. Nagarjuna adalah pendiri Madhyamaka (Jalan Tengah), sebuah aliran dari Budhisme Mahayana yang berakar pada tradisi filsafat India, kemudian menyebar dan berkembang ke Asia Tengah, Asia Timur (Cina, Korea dan Jepang), dan Tibet.

Dekonstruksi Derrida belakangan ini banyak pula digunakan dalam studi-studi kontemporer mengenai Budhisme, sebagai tinjauan untuk membahas persoalan yang diangkat oleh Nagarjuna. Sejumlah peneliti melihat paralelisme antara filsafat yang dikembangkan Derrida dan Nagarjuna, terutama pada cara pendekatan dekonstruksi. Banyak hal dapat digali dari pemikiran Budhisme, terutama Nagarjuna, dengan menggunakan pendekatan dekonstruksi Derrida. Sementara itu di sisi lain, diperoleh pula suatu bentuk dekonstruksi "yang lain", yang dapat memperkaya wacana dekonstruksi.

Baik pemikiran Derrida maupun Nagarjuna mengandung sofistikasi yang tinggi. Pintu masuk untuk memahami hal tersebut seharusnya melalui penelusuran latar belakang dan tradisi pemikiran mereka. Karena terbatasnya kesempatan dan ruang untuk perbandingan semacam itu, kajian ini hanya ingin menampilkan garis 
besar dekonstruksi yang dikembangkan Derridan dan Nagarjuna. Perkenalan awal ini diharap dapat menjadi pintu masuk yang menjembatani dua tradis berbeda dari filsafat Barat dan filsafat Timur, dalam hal ini Dekonstruksi dan Budhisme Mahayana, yang sekaligus menjadi penghubung waktu antara filsafat kontemporer dan filsafat dari abad ke-2 Masehi.

\section{Dekonstruksi Hierarki dan Dominasi}

Derrida pada awalnya mengembangkan pemikirannya di Prancis dan kemudian di Amerika Serikat. Hal inilah yang menjadikan pemikirannya bersifa trans-Atlantik dan hidup dalam dua bahasa, yakni Prancis dan Inggris, dari hal in saja dapat dilihat kompleksitas pribadi Derrida. Disamping itu, Derrida hidup dan dibesarkan dalam dua tradisi besar pemikiran filsafat abad ke 20 yang sangat mewarnai pemikirannya, yakni fenomenologi dan strukturalisme. Nama-nama seperti Husserl, Heidegger, Levinas, de Saussure dan para penerusnya (kaum strukturalis) dari abad ke 20, juga para filsuf klasik seperti Plato, Rousseau, Kant, Hegel, Marx dan Nietzsche memberi andil dalam membentuk pemikiran Derrida.

Pada abad ke 20, filsafat Barat berkembang pesat seiring dengan perubahan yang terjadi dalam masyarakat. Banyak persoalan yang merangsang munculnya pemikiran baru dalam dunia filsafat, ada keyakinan umum dalam filsafat bahwa kata-kata memadai untuk menghadirkan dan menjelaskan segala hal, bahwa kata-kata memiliki kekuatan rasional untuk membenarkan dunia. Anggapan ini oleh Derrida dinamakan logosentrisme. Logosentrisme merupakan istilah yang digunakan Derrida, untuk menjelaskan bentuk rasionalisme yang mensyaratkan suatu "kehadiran" di belakang bahasa dan teks. Gagasan, tujuan, kebenaran, makna atau acuan dari bahasa bertindak sebagai wahana yang tersedia dan nyaman dar sebuah ekspresi kehadiran (Rice, 1966: 173), dari situlah kemudian dikenal istilah "mentafsirkan kehadiran", yakni pemikiran yang mensyaratkan kehadiran tersebut. Hadir berarti berada dan terlibat dalam sesuatu hal dan juga pada kekinian. Tekanannya pada keadaan "Kini dan di sini", sehingga berdimensi ruang dan waktu. Hasil dari tradisi sesuatu yang dianggap sebagai "pusat" dan "asal" (Ward, 2003: 103)

Baik logosentrisme maupun metafisika kehadiran mendasarkan diri pada logika yang dikembangkan oleh Aristoteles. Selama berabad-abad prinsipprinsip berpikir ala logika Aristotelian telah menguasai pemikiran filsafat Barat. Pertama, prinsip persamaan, bahwa segala sesuatu itu identik atau sama dengan dirinya $(\mathrm{A}=\mathrm{A})$.

Kedua adalah prinsip non-kontradiksi, mengacu pada pendirian bahwa sesuatu itu senantiasa tidak sama atau berbeda dengan selain dirinya (Anon-A). Prinsip terakhir ini adalah prinsip penyisihan jalan tengah atau penyisihan dar kemungkinan ketiga (A/non-A). Prinsip ini menyatakan bahwa tidak ada alternatif selain A maupun bukan A, semua kemungkinan sudah tercakup di dalam A atau bukan A, sehingga menutup sama sekali kemungkinan di luar keduanya.

Akibat dari prinsip semacam ini, manusia cenderung berpikir dikotomis. Segala sesuatu harus jelas posisinya sebagai hitam atau putih, termasuk A atau non-A saja. Atas dasar pemikiran semacam ini berkembanglah logosentrisme yang menciptakan oposisi-oposisi, yang memiliki hierarki, yang berakhir pada dominasi dari suatu posisi terhadap posisi yang lain (Deschamps, 2003: 149156). Menurut Derrida, inilah ciri logosentrisme.

Pada suatu titik tertentu, muncul kesadaran untuk meninjau kembali halhal yang telah dicapai oleh filsafat Barat. Segala macam pendasaran yang menjadi fondasi bangunan filsafat Barat seperti logosentrisme dan metafisika yang kehadirannya mulai dipersoalkan oleh Derrida. Secara radikal, Derrida mempertanyakan gagasan-gagasan mengenai kebenaran, pengetahuan, prosedur, kehadiran dan otoritas seperti yang terkandung di dalam sejarah filsafat Barat (Collins, 2001). Upaya yang dilakukan oleh Derrida ini dapat dilihat sebagai upaya untuk melakukan penafsiran kembali filsafat Barat yang logosentris dan mendahulukan kehadiran. Filsafat Barat, kata Derrida, seperti halnya setiap pemikiran dan ungkapan merupakan "teks" yang dapat dibaca ulang, karena setiap teks senantiasa terjalin dari berbagai unsur, maka selalu ada kemungkinan untuk mengurai teks dan menyusunnya secara baru. Pembacaan ulang semacam ini dimaksudkan untuk menciptakan pemahaman serta makna baru sebuah teks dengan mengakomodasi berbagai hal yang selama ini terpinggirkan oleh logosentrisme dan metafisika kehadiran.

Upaya semacam inilah yang dinamakan dekonstruksi (deconstruction). Derrida menjelaskan maksud dekonstruksi dalam konteks pemikiran Heidegger tentang konsep Destruktion (penghancuran) dan Abbau (pembongkaran). Bagi Derrida, dekonstruksi bukanlah destruksi yang berarti penghancuran ataupun pemusnahan. Derrida menggunakan kata dekonstruksi untuk menjelaskan dua gerakan yang berlangsung yakni pengacakan dan juga penataan ulang.

Derrida menyatakan pula, bahwa Dekonstruksi terlalu sulit untuk didefinisikan dan diterjemahkan. Pertama karena istilah apapun yang digunakan untuk menerjemahkan atau mendefinisikannya, dengan menawarkan suatu makna ataupun konsep yang bersifat definitif, dengan sendirinya membuka peluang untuk berlangsungnya suatu operasi dekonstruktif. Kedua, Derrida menolak adanya konsep yang terlepas atau melampaui kata-kata. Derrida menolak adanya suatu konsep dekonstruksi yang hadir ke dunia yang berada di luar kata-kata yang terangkum di dalam berbagai frasa ataupun kalimat. Untuk menjelaskan suatu kata dibutuhkan kata-kata yang lain dan yang ada hanya kata-kata serta tidak ada yang berada di luar kata-kata, maka tidak ada suatu konsep yang berada di luar serta melampui kata-kata. 
Walupun sulit untuk didefinisikan namun Dekonstruksi dapat dijelaskan dengan menghubungkannya dengan hal lain seperti dalam konteks metafisika kehadiran. Seperti telah dijelaskan diatas,tradisi filsafat Barat telah dikuasai oleh metafisika kehadiran dan logosentrisme. Karena mengutamakan kehadiran, maka bahasa lisan yang lebih bersifat langsung dianggap lebih utama daripada bahasa tulis yang melalui perantaraan. Bagi Derrida, filsafat Barat selama ini menganggap dirinya sebagai logologi; ilmu tentang perkataan atau bahasa lisan. Perspektif ini, bahasa sama dengan phone; suara atau tuturan.

Seluruh tradisi filsafat Barat adalah logologi, hal ini tampak pada pemikiran yang dimengerti sebagai tuturan, dalam De la Grammatologie (1967), Derrida membahas bahwa para filsuf mulai dari Plato, Aristoteles, Rossueau, Hegel, Husserl, hingga Heidegger memiliki kecenderungan ini.

Hal ini berkaitan erat dengan kehadiran sebagai tema pokok bagi filsafat barat. Bagaimana Derrida menampilkan”yang lain” dari metafisika kehadiran? Jika filsafat sampai sekarang sama dengan logologi, maka Derrida ingin mengubahnya menjadi grammatologi, yakni ilmu tentang grammatologi, yakni ilmu tentang gramma, huruf-huruf, inskripsi, tulisan. Gramma adalah "tanda dari tanda" atau tanda yang menunjuk kepada tanda lain. Melalui grammatologi, Derrida melakukan dekonstruksi terhadap filsafat Barat, dengan melakukan pembalikan hierarki dari tuturan ketulisan.

In a classical philosophical opposition we are not dealing with the peaceful coexistence of a vis-à-vis, but rather with a violent hierarchy. One of the two terms govern the other (axiologically, logically, etc), or has the upper hand. To deconstruct the opposition, first of all, is to overturn the hierarchy at a given moment (Derrida, 1981: 41).

Jika metafisika berpendapat bahwa tanda secara umum merupakan hal yang bersifat sekunder, maka betapa lebih lagi tulisan, yang merupakan tanda dari tanda (Bennington, 1981: 42-43). Melalui penjelasan ini dapat dimengerti mengapa Derrida melakukan pembalikan yang besar dalam filsafat melalui grammatologinya. Jika tanda dipandang sebagai hal yang sekunder dalam metafisika kehadiran, maka tulisan menjadi hal yang sekunder dari yang sekunder, menjadi kurang berarti. Mengangkat tulisan dalam grammatologi, bukan saja menampilkan "yang lain" dari metafisika kehadiran tetapi juga mendekonstruksikannya. Melalui grammatologi, Derrida berusaha mengatasi oposisi antara ucapan dan tulisan, antara sesuatu hal dan tandanya, kehadiran dan ketakhadiran. Jika oposisi-oposisi ini dapat diatasi, maka hierarki yang ada dapat diruntuhkan dan dominasi yang terjadi dapat diakhiri. Dengan demikian, melalui grammatologi ini. Derrida menampilkan suatu dekonstruksi dalam filsafat.

\section{Dekonstruksi Oposisi Samsara dan Nirvana}

Sekitar delapan belas abad sebelum kehadiran Derrida, hiduplah seorang keturunan Brahmin dari India Selatan, bernama Arya Nagarjuna. Semasa muda ia banyak mempelajari berbagai jenis pengetahuan dari yang praktis, hingga filsafat, agama bahkan konon juga ilmu sihir. Nagarjuna kemudian menjadi seorang Buddhis dan menjadi Bhiksu (Zimmer, 1959: 518-519).

Nagarjuna mengembangkan pemikiran Budhis, yang diterima dengan baik di seluruh India. Sepeninggalnya. Pemikirannya berkembang hingga ke Asia Tenggara dan Asia Timur, juga melintasi Himalaya, ke wilayah Tibet dan Mongolia. Di Tibet, hingga kini pemikirannya masih dianut dan terpelihara dengan baik (Kajiyama, 1993: 7177).

Tradisi yang melatarbelakangi pemikiran Nagarjuna adalah Brahmanisme dan Budhisme. Tradisi Budhisme sendiri dapat dilihat dalam dua arah pemikiran yang berbeda yakni : Abhidharma (terutama dari aliran Sarvastivada) dan tradisi yang berkembang dari literature Prajnaparamita (Streng, 1993: 292-293). Jika secara umum Budhisme merupakan reaksi terhadap Brahmanisme, maka pemikiran Nagarjuna disamping bereaksi terhadap Brahmanisme, juga merupakan reaksi terhadap tradisi Budhis sendiri yang berkembang dalam filsafat Abhidharma dari kaum Sarvastivada.

Asumsi dasar pemikiran Nagarjuna adalah pandangan Buddhis, yang tujuan utamanya adalah membebaskan seseorang (semua makhluk) dari "penderitaan". "Penderitaan" ini disebabkan oleh ketidaktahuan, yakni berangkat dari suatu pandangan dan pengertian yang keliru terhadap realiatas. Realitas yang keliru terhadap realitas. Realitas seharusnya dipandang sebagai arus yang senantiasa bergerak dan tidak mempunyai inti yang bersifat permanen sehingga inti dari kenyataan adalah aunya ("kosong").

Seluruh pandangan dan pengertian pada hakikatnya tidak memiliki inti yang bersifat permanen."Penderitaan" terjadi karena sikap hidup yang berlatar belakang ketidaktahuan, karena menganggap kenyataan seolah memiliki inti yang bersifat soteriologis, dalam arti mengupayakan keselamatan melalui pemahaman yang benar dengan menghancurkan pandangan dan pengertian yang keliru, seolaholah segala sesuatu memiliki hakikat dalam dirinya sendiri (svabhava).

Ditinjau dengan kerangka pemikiran Derrida, dapat dikatakan Nagarjuna mengembangkan suatu dekonstruksi yang bercorak soteriologis. Dinyatakan bahwa kenyataan bersifat tidak tetap dan tanpa inti. Segala sesuatu saling berelasi dan saling mengkondisikan, satu sama lain membentuk kenyataan, inilah yang dikenal sebagai pratityasamutpada".

Kita menafsirkan pengasalan yang saling mengkondisikan dari segala sesuatu (pratityasamutpada) sebagai aunyata (kekosongan). Aunyata (kekosongan) merupakan suatu petunjuk, bukan suatu pikiran, 
gagasan, pedoman bagi kehidupan sehari-hari. Hal ini sendiri merupakan "Jalan Tengah" (MK,XXIV) (Inada, 1970: 8).

Oleh karena itu, Pratityasamutpada merupakan kenyataan yang dikenal sebagai aunyata ("kekosongan") dan perwujudan dari "jalan tengah", yakni jalan untuk mengakhiri penderitaan. Kecenderungan dalam pemikiran manusia untuk mengkonsepkan segala sesuatu yang dipahaminya. Hal itu juga berlaku terhadap aunyata. Bahaya ini disadari sepenuhnya oleh Nagarjuna.

Suatu pemahaman yang keliru mengenai aunyata dapat

menjerumuskan orang yang picik. Hal ini seperti suatu perampasan seekor ular ceroboh atau suatu pelepasan mantra secara keliru (MK. XXIV) (Inada, 1970: 11).

Nagarjuna melakukan dekonstruksi terhadap "ketidaktahuan" yang berakar pada pandangan dan pengertian yang keliru, yang juga dan terutama berlaku terhadap aunyata, dengan dekonstruksi ini maka aunyata itu sendiri pada akhirnya "kosong", dari sini dapat dilihat bahwa dekonstruksi yang dikembangkan Nagarjuna bersifat sangat radikal, dekonstruksi yang mendekonstruksi dirinya sendiri.

Sifat radikal ini juga dapat ditemukan dalam soteriologinya (ajaran tentang keselamatan). Tradisi Buddhis secara umum mengenal perbedaan antara nirvana dan samsara. Tradisi-tradisi Abhidharma dari Sarvastivada menggunakan dasar pertentangan antara nirvana dan samsara sebagai basis pemikiran mereka. Mereka menciptakan hierarki dari konsep tertentu terhadap konsep yang lain. Terhadap persoalan ini, Nagarjuna mengambil langkah yang sangat radikal yakni mendekonstruksi pertentangan antara nirvana dan samsara. Nagarjuna menjungkirbalikkan hierarki yang dibangun antara keduanya hingga hierarki tersebut menjadi runtuh. Hal ini dapat dilihat dari kutipan Mulamadhyamakakarika dari Nagarjuna sebagai berikut.

Samsara, yakni lingkaran hidup mati secara empiris, secara

hakiki tidak berbeda dengan nirvana. Nirvana secara hakiki tidak berbeda dengan samsara.Batas-batas (alam) nirvana adalah batas-batas dari samsara. Di antara keduanya tidak ada perbedaan sekecil apa pun (MK. XXIV) (Inada, 1970:19-20).

Tersebut diatas hanyalah satu contoh dari dekonstruksi yang dikembangkan oleh Nagarjuna. Ia mendekonstruksi oposisi dari dua titik soteriologi yang ekstrem antara nirvana dan samsara. Baik samsara maupun nirvana sesungguhnya merupakan realitas yang sama. Perbedaan-perbedaan yang dilakukan sesungguhnya adalah "kosong". Dekonstruksi merupakan cara untuk memperlihatkan "kekosongan" tersebut.

Perpaduan antara dekonstruksi dan soteriologi ini dapat ditemukan dengan jelas sekali pada bagian paling awal dan juga paling penting
Mulamadhyamakakarika (MK). Oleh Inada hal ini diberi label sebagai "Kredo Madhyamaka".

Aku memberikan penghormatan kepada Sang Buddha, Sang guru tertinggi yang telah mengajarkan ajaran pengasalan yang saling berhubungan, penghentian mulia dari semua konstruksi pemikiran yang bersifat fenomena (yakni, setiap kejadian yang “ditandai” oleh) :

Tiada-permunculan, tiada-pemadaman, tiada-kemusnahan, tiadakeabadian, tiada-persamaan, tiada-perbedaan, tiada-kedatangan [kepada Ada], tiada-kepergian [dari ada] (MK. XXIV) (Inada, 1970: 38)

Ayat di atas yang diawali dengan penghormatan kepada ajaran Buddha mengandung delapan hal yang lazim dikenal sebagai rujukan untuk menunjuk kepada suatu realitas keberadaan, yang dikenal sebagai "Jalan Tengah".

Persoalan besar dalam penulisan dekonstruksi adalah bagaimana menampilkan wacana ini, karena dekonstruksi mengkomunikasikan antara yang dapat terkomunikasikan dengan yang tidak terkomunikasikan. Dekonstruksi merupakan kegiatan yang senantiasa terkait dengan suatu pemikiran, pernyataan, atau yang ada. Karena itu baik Derrida maupun Nagarjuna memerlukan pemikiran atau pernyataan yang akan mereka dekonstruksikan. Artinya pemikiran mereka berdua bersifat parasitis yakni menempel pada pemikiran lain, agar pernyataanpernyataannya dapat hidup.

Kedua orang ini tidak dapat mengembangkan tesis mereka sendiri, sebab mereka berangkat dari tesis-tesis yang dikembangkan oleh para pemikir lainnya. Tesis-tesis tersebut merupakan media untuk kelangsungan pemikiran mereka. Tanpa media tersebut mustahil bagi Derrida dan Nagarjuna mengembangkan dan mengkomunikasikan pemikiran-pemikiran mereka.

Virus merupakan gambaran yang baik mengenai salah satu operasi lain dari Derrida untuk menghadapi logosentrisme, dalam diri virus terdapat undecidability (ketidaktentuan), yang menghindarkan diri dari kategori oposisi, seperti pernyataan apakah virus merupakan makhluk hidup atau bukan makhluk hidup. Meskipun demikian pengaruh virus dapat dirasakan makhluk hidup dalam bentuk kekacauan sistem yaitu ia menempel. Inilah cara yang ditempuh oleh Derrida untuk menghadapi logosentrisme dan metafisika kehadiran.

Alih-alih menghindarkan diri dari metafisika kehadiran dan logosentrisme, pemikiran yang dikembangkan Derrida justru menumpang hidup didalamnya. Tulisan-tulisan Derrida sering kali merupakan komentar terhadap karya-karya (teks-teks) orang lain yang memiliki sifat dan berperilaku sebagaimana halnya suatu virus, sesuatu yang dapat disebut sebagai the viral matrix. Beberapa contoh yang dapat diberikan misalnya: Plato ( $\mathrm{La}$ Dissemination), Rousseau (De la Grammatologie), Hegel (Marges, Glas), Husserl (L'Origine de la geometrie, La Voix et le phenomene), Heidegger 
(Marges), de Saussure (De la Grammotologie). Melalui cara ini Derrida dapat mengkomunikasikan pemikirannya secara mandiri bukankah hal tersebut juga harus didekonstruksi?

Hal yang sama juga terjadi dalam dekonstruksi yang dikembangkan suatu tesis pemikiran yang baru. Dapat dikatakan bahwa Nagarjuna, yaitu mengembangkan suatu teknik reductio ad absurdum (argumen yang disusun berdasarkan konsekuensi dan implikasi logis dari tesis yang dikemukakan, hingga pada akhirnya menghancurkan sendiri tesis awal tersebut) yang tidak menciptakan satu tesis pun. Nagarjuna menerima suatu bagian tesis secara hipotetis, dan melalui penyingkapan implikasi-implikasinya diperlihatkanlah suatu kontradiksi internal yang lepas dari perhatian lawan. Penolakan atas suatu tesis bukan berarti penegasan atas lawan dari tesis tersebut. Nagarjuna tidak memiliki tesisnya sendiri, tidaklah membangun silogisme dan mengemukakan argumen dan contohcontoh sendiri (Murti, 1968: 131-132).

Hal tersebut dapat dilihat pada karya terbesar Nagarjuna Mulamadhyamakakarika (MK): 13 bab pertama MK merupakan pembahasan berbagai kategori yang dikembangkn oleh Abhidharma (dari bab 1: pratyaya parika hingga bab 13: Samskara parika). Ini berarti yang menjadi tesis awal dar pemikiran Nagarjuna adalah pemikiran yang dikembangkan oleh para Abhidarmika. Sementara aunyata (kekosongan) yang menjadi pusat filsafatnya tidak pernah dibahas dalam suatu pembahasan tersendiri melainkan tersirat dalam semua pembahasan dalam MK.

Karena sifatnya yang demikian, maka orang-orang sering salah dalam memahami pemikiran Nagarjuna. Hal ini dapat dengan jelas dilihat pada Vigrahavyavartani (VV), yaitu diperlihatkan bahwa lawan-lawan Nagarjuna menyalahpahami "kekosongan" sebagai sebuah entitas.

Mereka melakukan reifikasi terhadap kekosongan dengan memandang "kekosongan" sebagai "sesuatu" padahal konsep "kekosongan" itu sendir adalah "kosong", dengan memahami kekosongan sebagai suatu entitas mereka mengkritik pandangan Nagarjuna. Pada kesempatan tersebut Nagarjuna membalas kritikan tersebut dengan menyatakan :

Jika aku membuat suatu proposisi apapun itu, maka oleh

karenanya aku akan mempunyai sebuah kesalahan logis. Tetapi aku tidak

membuat sebuah proposisi, maka oleh karenanya aku tidak berada dalam

kesalahan (VV) (Johnston, 1951: 29).

Dimaksud diatas dengan proposisi disini adalah proposisi penyangkalan atau negasi. Ketika "kekosongan" adalah "negasi sesuatu", ini berarti bahwa Nagarjuna masih berada dalam dualisme ada-tiada, hal ini bukanlah "jalan tengah" yang ditawarkannya.
Karena segala sesuatu yang disangkal tidak akan pernah eksis, aku tidak menyangkal sesuatu pun. Sehingga, [pernyataan]: "engkau menyangkal"-sesuatu telah engkau buat merupakan suatu tuduhan yang keliru (VV) (Johnston, 1951: 64).

Dekonstruksi Nagarjuna bukanlah suatu bentuk penyangkalan atau negasi dari suatu hal. "Kekosongan" bukanlah suatu pandangan yang bersifat nihilistik. Nagarjuna bersifat mengatasi oposisi ganda seperti eternalisme (ada secara mutlak) nihilism (tidak ada secara mutlak), baik itu "ada" maupun "tiada" keduanya bisa mempunyai nilai yang "kosong" ataupun "ada".

Penjelasan di atas memperlihatkan bahwa "kekosongan" adalah sesuatu yang sukar untuk dikomunikasikan. Walaupun sukar untuk dikomunikasikan, bukan berarti "kekosongan" merupakan sesuatu yang tak dapat dikomunikasikan dalam/ oleh bahasa. "Kekosongan" terletak diantara "yang terkomunikasikan" dan yang tak terkomunikasikan". Persoalan ini dipecahkan dengan menggunakan "dua jenis kebenaran" yakni samvti satya (kebenaran biasa/ sehari-hari) dan paramartha satya (kebenaran tertinggi). Segala sesuatu yang dapat dikomunikasikan merupakan kebenaran sehari-hari yang relatif dan saling mengkondisikan (samvti satya), sedangkan suatu kebenaran yang sejati dan bersifat nonkondisional (paramartha satya) merupakan sesuatu yang tak dapat dikomunikasikan.

Ajaran Dharma dari bermacam Buddha didasarkan kepada dua

jenis kebenaran Yakni, kebenaran relatif sehari-hari (samvti satya) dan

kebenaran absolut tertinggi (paramartha satya). Barang siapa yang tidak mengetahui perbedaan antara kedua kebenaran, tidaklah dapat memahami hakikat ajaran Buddha yang dalam. (MK. XXIV) (Inada, 1970: 8-9).

Dua jenis kebenaran yang ditawarkan di sini bukan suatu oposisi ganda atau suatu jenis dualisme. Dua jenis kebenaran bukanlah menyatakan tentang dua jenis realitas melainkan satu realitas yang dinyatakan dengan cara atau suatu pandang yang berbeda. Kedua jenis kebenaran tersebut saling melengkapi dan menyempurnakan.

Tanpa menyandarkan diri pada praktik umum setiap hari (yakni

kebenaran relatif), kebenaran absolut tidak dapat diungkapkan. Tanpa pendekatan terhadap kebenaran absolut, nirvana tidak dapat dicapai. (MK XXIV) (Inada, 1970: 10)

Samvti satya dan paramartha satya bukanlah dua bidang yang berbeda yaitu ditempatkan objek. Keduanya dapat dibedakan, namun tetap mengacu pada objek yang sama (dalam pengertian epistemologis dan bukan ontologis). Pembedaan antara Samvti satya dan paramartha satya merupakan suatu pembedaan yang dilakukan dengan tujuan yang bersifat soteriologis. 
Hal-hal diatas merupakan gambaran dari dua gerbang dekonstruksi yang dikembangkan Derrida dan Nagarjuna. Hal pertama yang menghubungkan keduanya ialah sikap kritis terhadap tradisi tempat mereka hidup. Derrida bereaksi terhadap tradisi yang berkembang sepanjang sejarah filsafat Barat. Derrida mempertanyakan kembali pendasaran yang paling fundamental dalam filsafat Barat secara radikal sementara Nagarjuna bereaksi terhadap pandangan non-Buddhis maupun pandangan Buddhisme yang berkembang pada masa itu. Malahan, pandangan Nagarjuna bahkan juga dapat menjangkau pandanganpandngan yang muncul kemudian. Persamaan kedua adalah penolakan terhadap penggunaan logika yang beroposisi ganda. Para pemikir lain mungkin saja bersikap kritis terhadap tradisi yang berkembang dalam lingkungan pemikiran mereka, namun sikap kritis yang mereka kemukakan tetap bertahan dalam penalaran logika yang beroposisi ganda, yakni penolakan secara frontal terhadap suatu pandangan yang mereka jadikan titik tolak acuan. Walaupun tampaknya melawan, namun kedua pandangan yang berlawanan tersebut akhirnya menampakkan titik tolak yang sama juga.

Derrida menolak menggunakan logika ini karena tradisi pemikiran yang dikritiknya bertumpu pada logika tersebut. Usaha yang dilakukan justru bermaksud agar logika ini tidak berfungsi. Nagarjuna pun melakukan hal yang sama. Nagarjuna melihat bahwa semua jenis pemikiran disusun atas dasar logika dualis, bahkan juga dalam pemikiran Abhidharma Buddhisme. Hal ini merupakan akar kesalahan yang mengakibatkan seseorang jatuh dalam "penderitaan". Usaha untuk mengatasi "penderitaan" tentunya juga mencakup usaha untuk mengatasi logika dualis ini.

Persamaan ketiga, menyangkut soal kenyataan. Menurut mereka segala sesuatu bukanlah hal yang real secara intrinsik, melainkan hanya berada dalam relasi dengan yang lain. Segala sesuatu bersifat relatif. Derrida menyatakan "segala sesuatu tidak ada yang berada di luar teks". Dengan demikian segala sesuatu selalu bersifat intertekstualitas. Relasi antarteks inilah yang menentukan, dan bukan hal yang bersifat instrinsik yang melekat dalam diri sesuatu. Sementara Nagarjuna juga menyatakan hal serupa dengan bersandar kepada doktrin pratityasamutpada (pengasalan yang saling berelasi dan mengkondisikan). Hal ini berhubungan pula dengan doktrin "jalan tengah" dan "kekosongan". Realitas adalah realitas yang berkondisi dan berelasi. Satu hal senantiasa dikondisikan dan dihubungkan dengan hal-hal yang lain. Nagarjuna menolak kenyataan yang bersifat substantif intrinsik dari segala sesuatu. Tidak ada sesuatu yang bersifat absolut melainkan relatif.

Kedua pemikiran penyadari bahwa terdapat kesulitan untuk mengkomunikasikan pemikiran mereka, namun toh masih ada cara yang dapat ditempuh. Bagi Derrida, kebenaran yang berada di dalam teks bukanlah kebenaran tertinggi, namun selain itu tidak ada kebenaran lagi. Ini sejalan dengan Nagarjuna yang menyatakan bahwa tanpa kebenaran sehari-hari kebenaran tertinggi tidak dapat diungkapkan. Sebaliknya tanpa bersandar kepada kebenaran tertinggi, Nirvana tidak akan tercapai.

Demikianlah sejumlah persamaan antara kedua pemikir dekonstruksi Derrida dan Nagarjuna. Sejauh ini hanya diketemukan hal-hal pokok dari pemikiran mereka, meskipun demikian paling tidak terdapat manfaat yang dapat diambil dari kajian ini, dari sisi Derrida, dekonstruksi Nagarjuna memberikan gambaran tentang dekonstruksi "yang lain". Suatu bukti yang memperlihatkan bahwa terdapat suatu bentuk dekonstruksi lain yang hidup dan berakar di luar tradisi filsafat Barat. Hal ini tentunya akan memberikan masukan baru terhadap wacana yang dikembangkan dekonstruksi.

\section{Imajinasi dan Dekonstruksi dalam Posmodern}

Imajinasi adalah kemampuan mencipta imago, image, atau citra; sekaligus menunjukkan kondisi ketergantungan manusia pada citra tersebut. Imajinasi diciptakan oleh pikiran dan menjadi alat bantu pikiran untuk menyusun sebuah (atau berbagai) ide dan konsep. Melalui imajinasi, manusia bisa menetapkan juga mengatur keberadaan diri dan juga dirinya terhadap orang lain, misalnya dengan cara menciptakan bahasa. Maka imajinasi pada dasarnya adalah (juga) konstruksi sosial dalam pikiran manusia, dan apa yang tengah berlangsung semakin penting dan kompleks dewasa ini, tetapi justru hal yang terutama sering orang remehkan, adalah "kenyataan" bahwa imajinasi adalah juga bentuk praktik sosial. Imajinasi, kini telah menjadi suatu wilayah terorganisasi dari berbagai praktik sosial, menjadi semacam bentuk "kerja", serta bentuk negosiasi antara individu (sebagai agen) dengan berbagai kemungkinan persoalan secara global (Zaelani, 2002: 90).

Pandangan posmodern terpengaruh oleh adanya Revolusi Grafis yang kini melanda dunia, terutama melalui ledakan kekuatan teknologi baik dalam media massa maupun televisual. Pada tahap inilah imaji yang sifatnya representasional malahan semakin menutupi realitas itu sendiri dan ekstremnya, ia "membentuk" realitas. Salah satu ciri yang perlu dilihat ialah bahwa kebanyakan para filsuf posmodern menolak ide dasar tentang "asal usul" (origin) yang selama ini menjadi pembicaraan penting. Makna (meaning) didekonstruksi menjadi sebentuk permainan signifikasi-signifikasi linguistik yang tak pernah berakhir, dan setiap signifikasi saling berkaitan satu dengan yang lain dalam suatu lingkaran parodik (Kearney, 1972: 252). Tampak bahwa pandangan postmodern seolah-olah kembali ke pandangan Platonis yang bersifat mimesis, namun yang kini tak mengenal asalusul dan akhir. Mimesis adalah demi mimesis. 
Tokoh-tokoh pemikir seperti : Lacan, Althusser, Foucault, Levi-Strauss, dan Derrida tampaknya menyingkapkan "sistem tak sadar" bahasa sebagai kunc untuk membongkar pemahaman imajinasi kaum humanis yang dipahami sebagai entitas (ada) yang otonom. Lacan sendiri, meyakini bahwa ilusi-ilusi imajiner mesti diurai agar bahasa simbolis ketaksadaran yang ada di belakangnya "terdengar". Diri-imajiner (imaginary) Seo harus mati supaya diri simbolik symbolic seo hidup (Kearney, 1972: 257).

Demikianlah Lacan menyerang ilusi akan adanya otonomi diri (the image of unified selfhood) yang disamakannya dengan "yang imajiner". Imago bukanlah kreasi otonom dari keinginan seorang anak, tetapi sebentuk simulasi dari apa yang diharapkan ibu terhadap anak itu. Namun bagi Lacan, yang imajiner itu akan menjadi akar narsisisme, yang kelak juga menjadi akar humanisme (Lechte, 1994: 40) Althusser punya pandangan yang serupa, namun dalam konteks sosial Marxis. Althusser menyamakan yang imajiner dengan "kesadaran palsu" kaum borjuis (Kearney, 1972: 261), selanjutnya menyatakan bahwa ideologi adalah "representasi relasi imajiner dan subjek dengan kondisi real eksistensinya” (Lechte, 1994: 123)

Destruksi atas relasi imajiner ini karenanya mengarah kepada revolusi dalam keseluruhan dialektikan pengetahuan dan sejarah. Sementara itu, Foucault yang mengumandangkan "kematian manusia" (the death of man) mengimplikasikan penghancuran paham imajinasi kreatif yang selama in diagungkan para idealis dan eksistensialis modern. Bersamaan dengan "kematian manusia", mati pulalah segala daya yang dimilikinya, dan manusia tidak lebih dar satu titik yang terperangkap dalam strukturalisme sejarah dan arkeolog pengetahuan (Barthes, 1977: 142). Barthes pun memiliki pandangan yang mirip dengan Foucault dalam hal meyakini kematian imajinasi yang otoritatif.

Barthes mengekspos berbagai tanda tersembunyi di dalamnya. Ide tentang subjek yang imajinatif dan kreatif karenanya hanyalah suatu "mitos" sebagaimana juga imajinasi kolektif. Berada dalam lingkungan ilusi ideologis ini, tak punya plihan lain yaitu masuk ke dalam "malam gelap sejarah" suatu daerah kosong tanpa orientasi.

Sebuah esainya yang kontroversial, "The Death of the Author", Barthes mengumumkan kematian imajinasi para humanis. Suatu karya sastra mestinya tidak dipahami sebagai "ekspresi" subjek (pengarang, the author) yang kreatif, tetapi sebagai permainan impersonal tanda-tanda linguistik (tulisan). "Hidup"nya sebuah teks mempra-andaikan kematian sang pengarang. Kini penemuan bahasa sebagai sistem yang independen terhadap subjek menunjukkan bahwa sang pengarang tidaklah lebih dari pihak yang menulis, seperti Aku tidak lain adalah pihak yang mengatakan "Aku" (Barthes, 1977: 142). Bersamaan dengan "kematian" pengarang, tidak ada lagi imajinasi yang otoritatif.
Puncak dekonstruksi postmodernisme terutama dalam hubungan dengan bahasa karenanya juga dalam kaitan bahasa dengan imajinasi ini semua terletak dalam pandangan Jacques Derrida. Dua pokok dalam pandangan Derrida : Mimesis tanpa asal-usul (mimesis without origin) dan apokalips tanpa akhir (apocalypse without end).

\section{(1) Mimesis itu tanpa asal-usul.}

Derrida mengatakan, bahwa cara terbaik untuk mendekonsstruksi metafisika asal-usul (origin) adalah dengan mendalami penyelidikan atas "menulis" ( $e^{\prime}$ criture). Derrida mengacu pada terminologi "menulis" yang meliputi segala aspek pengalaman yang ditandai dengan jejak-jejak signifikasi. Tidak ada peristiwa awal dalam suatu lingkaran makna. Sebaliknya, yang ada adalah repetisi dan reiterasi"Menulis" karenanya adalah sebentuk mimesis. Sekilas, pandangan ini seolah-olah kembali kepada pandangan Plato tentang mimesis, namun yang dipahami dalam pandangan Derrida ini sama sekali menolak paham asal usul (originalitas). Plato membandingkan jiwa manusia dengan sebuah buku (bibos) yang mengkopi dan mengilustrasikan pengalaman manusia dalam proses "menulismimetik" yang dilakukan oleh "penulis internal" (grammateus) dan "pelukis internal" (zo"graphos-de"miurgos).

Pandangan Derrida, mimesis tidak mengacu pada dekonstruksi ganda terhadap paham asal usul dan terhadap pemahaman akan mimesis dalam teks Mallarme berjudul Mimique.

Apa yang terjadi dalam mimesis sebetulnya adalah dekonstruksi diri (self deconstruction). Tidak ada imitasi terhadap "sesuatu". Peniruan tidak mengimitasi apa pun. Gerakan yang terjadi dalam "menulis" membentuk figur dan imaji yang tidak dapat diasalkan pada ucapan yang mendahuluinya. Orang sekarang memasuki suatu "labirin tekstual yang dikelilingi banyak cermin". Ketika orang mengatakan telah "mengimitasi sesuatu", yang terjadi sebetulnya adalah orang "mengimitasi imitasi". Parodi yang sesungguhnya adalah parodi atas parodi. Paradigma parodi itu "sekaligus imaji dan model, namun juga imaji tanpa model, tanpa kenampakannya sebagai benar atau real (verisimilitude), tanpa kebenaran atau kesalahan, suatu peniruan tampilan tanpa realitas yang disembunyikannya, tanpa dunia apa pun di baliknya" (Derrida, 1981: 211)

Derrida memulai suatu dekonstruksi pula atas oposisi antara imajinasi dan realitas yang menurutnya paling tepat diekspresikan dalam figur postmodern yakni permainan. Mengapa? Karena dalam permainan parodi, imitasi meniru imitasi dalam lingkaran alusi (sindiran) yang tak pernah berakhir dan tak punya awal. Orang juga tak pernah mengetahui alusi itu mengalusi apa, kecuali bahwa yang terjadi adalah sebuah proses alusi. Barthes juga pernah menjelaskan tentang secondary mimesis yang dilakukan oleh prara pelukis realisme sebagai pengacuan dari satu kode ke kode yang lain, dari satu kopian ke kopian yang lain.” Kearney 
selanjutnya membuat beberapa kesimpulan penting dari bagian "mimesis tanpa asal usul" dari Derrida :

Pertama, orang tak dapat lagi mengajukan pertanyaan : apakah itu imajinasi? Karena pertanyaan semacam itu mengandaikan bahwa ada sebentuk "esensi" dari imajinasi yang akan membedakannya dari dunia real di sebaliknya. Dunia ini adalah sebuah teks yang tak berawal dan berakhir.

Kedua, orang tak dapat lagi bertanya : siapa yang berimajinasi? karena paham asal usul telah diruntuhkan, dan tak ada lagi pengarang atau penulis suatu teks.

Ketiga, orang tak dapat lagi bertanya : bagaimana orang dapat keluar dari parodi? karena imajinasi yang didekonstruksi menjadi suatu parodi atas dirinya sendiri itu telah mengabaikan segala pembedaan metafisis terhadap "yang di dalam" dan "yang di luar". Tidak ada suatu "jalan keluar" karena tidak relevan lagi. (2) Apokalips tanpa akhir.

Istilah "apokalips" di sini sebenarnya berarti, suatu "penyingkapan" (uncover,apokaluptein). Derrida membuat sebuah perbandingan saling dekonstruktif dalam tulisannya berjudul Glas, menampilkan dua kolom tulisan satu sastra dan satu filosofis yang mengolah apokalips suci St. Yohanes dan apokalips profan Jean Genet. Derrida mengomentari keduanya dengan analisis dekonstruktif terhadap kata. "datang" (come). Kata ini disebutnya sebagai yang memperkuat nada apokaliptik. Kata ini juga membuka suatu permainan dekonstruktif tanpa pernah menjadi objek di bawah tatanan logosentris. Kata "datang" tak dapat diura maupun diinterprestasikan dalam suatu analisis atas kata tersebut; karena ia adalah suatu alamat tanpa subjek : orang tidak tahu siapa yang berbicara atau kepada siapa kata itu diarahkan serta kata itu tak bisa disituasikan secara temporal. Derrida membatalkan saat naratif-linier imajinasi manusia.

Pada akhirnya, ciri dekonstruktif pemahaman kata "datang" itu meruntuhkan berbagai upaya konseptual maupun linguistik untuk memutuskan makna dari sesuatu. Bahasa hanyalah suatu parodi atas parodi, bukan lagi parodi atas kehidupan atau apa pun. Orang bahkan tidak dapat mengimajinasikan apa itu "kebenaran" dalam pemahaman apokalips tanpa akhir ini. Apokalips tanpa akhir hanya dapat dipahami sebagai suatu "akhir yang tak berakhir". Bisa jadi bahwa filsafat tentang imajinasi sudah "runtuh" sejak Derrida (Brian Wallis, 1987: 27).

Apakah benar demikian, orang tidak hendak langsung menyetujuinya sekarang, sebab dekonstruksi pun masih men gandaikan suatu re-konstruksi. Sebagaimana dikatakan oleh Lechte, Derrida sesungguhnya telah mengubah teks "primer" menjadi sumber inspirasi dan kreativitas yang baru. Kini para kritikus dan pembaca suatu teks tidaklah sekadar menginterpretasikan, tetapi bahkan menjadi seorang pengarang. Jadi, dalam konteks pengertian dekonstruktif pun mesti dipahami bahwa imajinasi, inspirasi dan kreativitas harus dipahami dan dirumuskan secara baru.

\section{Konstruktif maupun Dekonstruktif}

Fungsi ini tampak dalam cara kerja yang bersifat "membangun" atau "menjembatan" berbagai konsep atau imaji dari persepsi, sehingga dibentuklah gambaran baru yang memungkinkan pemahaman (understanding) (Lechte, 1994: 109). Orang cenderung mengatakan bahwa fungsi imajinasi ini sangat positif. Tetapi, bila orang berhenti pada pemahaman ini, maka imajinasi bisa jadi tampak tidak lebih kreatif.

Kreativitas yang bersifat lebih dari imajinasi itu sesungguhnya baru muncul setelah orang memahami fungsi dekonstruktif. Fungsi ini mengandaikan bahwa imajinasi tidak sekadar membangun keterkaitan konsep atau imaji dalam suatu keseluruhan keterpahaman (inteligibilitas) yang kokoh, melainkan juga meruntuhkan keseluruhan itu menjadi fragmen-fragmen yang sering kali tak berhubungan lagi.

Imajinasi menjadi semacam self-deconstruction, penghancur apa yang dihasilkan sendiri. Memecah-mecah keseluruhan itu menjadi kepingan-kepingan atau bahkan kadang-kadang menjadi butiran-butiran debu atau remah-remah yang tak berarti lagi. Hanya imajinasilah yang sanggup melakukan ini, melepaslepas unsur-unsur yang menyusun keseluruhan, namun tidak sebagaimana ketika mengkonstruksinya, hingga menghasilkan fragmen-fragmen yang sama sekali lain dengan "bahan dasar"-nya.

Berdasarkan pada pemikiran tersebut, kini saya dapat mengerti sejauh mana imajinasi dapat menguasai jalan pemikiran dan proses pengetahuan sekaligus proses kreasi yang diinginkan. Apabila pada suatu saat saya sampai pada salah satu "puncak") kreasi/ pengertian) yang dipandang sebagai kebenaran, maka saya berhak dan mampu melalui daya imajinatif untuk "menunda" pengakuan akan "puncak" itu sementara. Kemudian saya dapat mendekonstruksi (meruntuhkan) "puncak" tersebut untuk mendapatkan pemahaman lain yang lebih utuh.

Pada tataran rasional, falsifikasi ini berurusan dengan upaya mencari kelemahan, kesalahan, dan tak-bisa-diterapkannya teori-teori yang ada, untuk mendapatkan teori baru yang yang lebih mampu mengatasinya. Sementara itu pada tataran imajinatif dapat dikatakan bahwa prinsip fasifikasi tanpak pada fungsi dekonstruktif imajinasi yang merombak dan mengurai suatu keselurahan imaji atau gambaran untuk membentuk kembali gambaran yang lebih menyeluruh daripadanya. Oleh karenanya fungsi dekonstruktif imajinasi ini membawa pengertian baru, yakni proses 're-konstruksi'. Re-konstruksi berbeda dengan rekontruksi. Re-konstruksi (mental atau) imajinatif bukan sekadar proses 
membentuk kembali gambaran berdasarkan imaji-imaji yang sudah ada atau sudah pernah dipersepsi melalui indra, melainkan dari fragmen-fragmen imaji hasil dekontruksi. Bedanya, fragmen-fragmen ini tidak sama dengan imaji-imaji mandiri yang sudah ada saat dipersepsi atau dimunculkan dalam pemikiran, tetapi hanya dapat muncul dari proses dekonstruksi atas suatu imaji, dengan demikian fragmen-fragmen tersebut belum pernah muncul sebelum proses peruntuhan keselurahan imaji bentukan imajinasi.

Re-kosntruksi hanya mungkin sesudah dekonstrusi, sedangkan rekonstruksi tidak harus mengandaikan dekonstruksi. Akhirnya dapat dikatakan bahwa re-konstruksi adalah tahap ketiga yang terjadi sesudah konstruksi dan dekonstruksi. Penjelasan tersebut diatas, hendak ditunjukan disini bahwa imajinasi memiliki kemampuan membangun, menghacurkan, dan membangun kembali suatu imaji, dan semuanya itu terjadi secara mental. Tanpa hendak menyamaratakannya dengan fungsi rasio yang menerapkan prinsip-prinsip yang lebih logis sesuai katagori yang diterima umum, disitu lebih ditekankan kemampuan imajinasi untuk lebih dahulu "meramalkan" suatu imaji, ini berbeda dengan kemampuan intuisi yang bersifat "lebih segera" melihat kebenaran. Imajinasi masih membawa nuansa proses dalam ketiga fungsinya diatas, sehingga tanpa harus secara presisi mengikuti silogisme (rasional), ia tetap mampu mengahasilkan "gerak" imajerial yang dapat dipertanggungjawabkan.

Sebetulnya pemahaman akan re-konstruksi ini membuat orang memahami proses dekonstruksi secara lebih tepat dan "pada tempatnya". Dekonstruksi itu memecah-mecah suatu keseluran atau tatanan (imaji) yang sudah ada, namun ke dalam fragmen-fragmen yang sama sekali berbeda dengan imaji-imaji awal pemberntukannya. Akhirnya dalam pemahaman ini dapatlah dimengerti bahwa siapa saja dapat memiliki imajinasi yang "otoritatif", atau juga keyakinan bahwa imajinasi yang otoritatif itu tidak menjadi persoalan penting lagi dalam era dekonstruktif ini.

Sebagaimana telah diingatkan oleh Foucault dan Barthes, subjek ini bukan menjadi yang terpenting lagi. Memang imajinasi tetap merupakan suatu daya manusiawi dan karenanya membutuhkan kreativitas subjek yang mengimajinasikan, dalam konteks fungsi re-konstruksi imajinasi, kreativitas itu bergantung bukan pada subjek pertama yang memunculkan suatu imaji, melainkan pada siapa saja yang mampu mendekonstruksi suatu imaji dan mere-konstruksinya. Bandingkanlah pandangan ini dengan pandangan Derrida sendiri yang memungkinkan bahwa siapapun dapat menjadi pengarang atau penulis sebuah teks (Derrida, 1981: 287-299). Justru di dalam kemampuan re-konstruksi imajinasi itulah terdapat "orisinalitas" dalam pemaknaannya yang sudah bergeser. Kreativitas dan "orisinalitas" kini dilihat dari kemampuan orang mengkonstruksi, mendekonstruksi, dan mere-konstrusi imaji.

\section{Seni lukis/ Instalasi dan Dekonstruksi}

Sekarang muncul gairah baru dan harapan besar terhadap wacana-wacana perbedaan yang dihembuskan oleh semangat dekonstruksi, misalnya terlihat dari munculnya disiplin-disiplin baru seperti pascakolonialisme, multikulturalisme, feminisme, orientalisme, 'kajian budaya' (cultural studies), dan seterusnya.

Di seni lukis jalan menuju dekonstruksi seperti ini orang dapat mengikuti sejak maraknya eksperimen yang muncul seperti kubisme, minimalis, avant-garde dan neo-avant-garde, seni populer, dan sebagainya. Para perupa dan kritikus secara intens mempersoalkan teknik, performansi, tema, media ekspresi, ruang, dalam kaitannya dengan persoalan dasar proses kreatif terutama mengenai potensi-potensi seperti insting, imajinasi, keterampilan, dan terutama ide. Eksperimen-eksperimen dalam seni lukis ini tidaklah terpisah dengan perubahan-perubahan struktur kehidupan akibat berbagai peristiwa seperti Perang Dunia, perang Vietman, penemuan teknologi informasi, dan sebagainya.

Peradapan mungkin merupakan sebuah beban makna yang harus dipikul seperti dalam mitos Sisipus, namun tidak harus mengangkatnya dan menaruhnya ke atas puncak bukit terus dan terus. Mengapa peradaban harus dihadapi dengan begitu serius mitos itu? Kendati peradapan boleh-boleh saja dianggap hanyalah sebuah eksperimen dari gairah bermain. Tetapi konstruksi Modernisme sudah terlampau jauh menganggapnya beban di mana semua orang harus sanggup memikulnya dan mempertanggungjawabkannya.

Karya-karya dari pemikir pascastrukturalis menekankan dimensi marginal (parole) untuk lebih mengakses gairah permainan yaitu eksotismeeksotisme yang selama ini terdiam oleh grand-design Modernisme bisa tampil semarak.

Di dalam wacana praktik seni lukis, orang kembali memperhatikan "aura kosmologi" yang membuatnya kembali belajar pada tradisi di samping batasbatas seni lukis yang semakin kabur ketika ruang lingkupnya ditembusi oleh media-media ekspresi lainnya. Munculnya seni instalasi, seni performans, dan kolase membuat seni lukis tidak lagi sebatas cat, kuas, dan kanvas. Mungkin orang akan lebih enteng menyebutnya dalam pengertian luas, yakni seni rupa kontemporer. Tetapi tidak pada tempatnya perubahan pengertian seperti ini dipersoalkan lebih lanjut.

Apa yang menarik ialah konsep identitas sama sekali tidak lenyap sekalipun wacana tentang perbedaan menyeruak semarak. Seharusnya konsep identitas dan perbedaan menjadi dua unsur yang kontradiktif, tetapi orang tidak perlu melihatnya dari kacamta dikotomistik seperti itu.

Suatu perbedaan mencolok dari problem konsep identitas ini ialah apabila identitas Modernisme mengurung dirinya ke dalam kesadaran makna tunggal, maka konsep identitas pada pemikiran dekonstruksi menjadi membagi diri ke 
dalam berbagai makna, makna ini selalu tak terelak bergerak dari wilayah persepsi kosmologis masing-masing diri (subjek). Subjek yang seperti apa? Jelas subjek atau kesadaran diri disinipun disadari tidak pernah utuh dan bulat. Subjek menjadi semacam kesadaran yang terbentang dan meluas tanpa batas (deseminasi) (Awuy, 2002: 97).

Persepsi kosmologis tidak lain merupakan persepsi tentang ruang-ruang batas tertentu. Manusia atau objek tidak pernah muncul tiba-tiba atau terlempar begitu saja di muka bumi. Realitas sosiokultural membentuknya terutama lewat bahasa. Kesadarannya dengan demikian merupakan semacam konstruksi tekstual yang sebenarnya sudah dibawanya dari wilayah bawah sadar baik tubuh dan wilayah psikis subjek menjadi sebuah teks yang memancarkan tanda-tanda untuk kemungkinan dibaca.

Ekspresi seni dari subjek dalam anggapan di atas merupakan representas dari teks-teks yang kompleks semacam wilayah keluar masuk antara kesadaran dan bawah sadar atau mengingat dan melupakan. Subjek dapat pula pada proses awal identitas tekstualnya ketika kesadarannya hanya terkonsentrasi pada satu kemungkinan teks dan mampu mengingat-ingat lagi ketika struktur kesadarannya dibuka dengan teks yang berbeda. Hal ini biasa disebut sebagai proses familiarisasi dan defamiliarisasi subjek (Awuy, 2002: 97).

Ketika orang menyaksikan seni rupa kontemporer menampilkan beragam ikon-ikon etnik dari sini sebenarnya orang dapat memahami bahwa gejala tersebut merupakan ungkapan dari proses defamiliarisasi untuk kembali mempersoalkan identitas subjek. Ketika sebuah negara lepas dari kolonialisasi maka dapat kembali mengingat lagi pada sesuatu yang selama ini terpendam karena represi. Kemudian akan muncul kesadaran akan makna identitas kultural dan praktis mambawa orang pada makna identitas diri. Gejala ini membawa orang pula pada persoalan yang lebih detail yakni problem identitas etnik yaitu kemampuan parole orang semakin transparan. Katakanlah arti dari parole di sini ialah indigenous culture.

Seni Instalasi di Indonesia pada awal kemunculannya adalah

perkembangan dari gerakan seni yang mempertanyakan pandangan sen modern. Sekarang ini perkembangannya agaknya tidak dapat dipisahkan dengan seni kontemporer. Seni instalasi ini mempunyai faham yang sangat luas, tidak sekedar respon, pameran atau display, tetapi kemudian jarak antara audience dan karya menjadi hilang bahkan bisa saja menjadi satu. Instalasi dapat juga disebut sebagai hybrid, di dalamnya ada banyak disiplin ilmu, misalnya arsitektur, performance art dan juga mengangkat atau membicarakan banyak konteks serta suasana sekaligus lokasi bisa menjadi pertimbangan seniman dalam berkarya.(Oliveria, 1998: 7-8)

\section{Dekonstruksi Diri Sendiri Kaitannya dengan Landasan Penciptaan} Karya

Pada bagian ini mengurai tarikan-tarikan simbiosi dan mensintesakan kaitan antara "teks" (bahasa) ditransformasikan ke "konteks" sebagai titik tolak landasan penciptaan, tetapi terlebih dahulu sebelum mengurai "tekstual" ke "kontekstual", saya akan mengemukakan terlebih dulu pradekonstruksi, yaitu penciptaan karya "retak-retak" yang dulu saya pernah ciptakan, sebagai acuan wacana kilas balik dan berikut ini tanggapan dari para pengamat yang saya anggap mewakili di era retak-retak.

\section{Simbiosis Dekonstruksi}

Dekonstruksi bagaikan angin segar, yang membangunkan saya dari tidur yang melelahkan dari alam stagnant. Semangat dekonstruksi membangun daya kreasi dan imajinasi. Dekonstruksi diri sendiri membuat gebrakan kreasi tak berawal dan berakhir, memberdayakan imajinasi, mengkomunikasi yang belum terkomunikasi selama ini terepresi oleh identitas (tunggal) sterio tape/ famili style.

Dekonstruksi diri sendiri, artinya membongkar mengosongkan (aunyata), menyingkap"Sistem tak sadar", member "daya" kan imajinasi, agar di balik ketaksadaran, muncul ide-ide "liar" yang selama ini belum pernah diungkap dalam karya. Dekonstruksi diri sendiri yaitu mendekonstruksi imajinasi "retakretak, dengan menyingkap/ mengkritisi, yang belum pernah terungkap menjadi bentukan kreasi yang lain ("baru”).

\section{Konstruksi, Dekonstruksi, Re-konstruksi}

Konstruksi : Imajinasi retak-retak dulu yang tertata, sistematis (terukur).

Dekonstruksi : Membongkar tatanan retak-retak, mengkritisi, menyingkap yang belum terkomunikasikan, agar muncul, menjadi fragmenfragmen kemungkinan-kemungkinan yang baru (relativitas).

Re-konstruksi : Menata ulang bentuk-bentuk imajinasi dekonstruksi berupa fragmen, sebagai daya imajinasi baru untuk dikreasikan (tak terbatas).

Apabila kreasi saya sudah sampai ke "puncak" suatu kebenaran kreasi, dengan daya imajinasi untuk "menunda" pengakuan akan "puncak" untuk sementara. Kemudian saya dapat mendekonstruksi (membongkar/ meruntuhkan) "puncak" tersebut untuk mendapat pemahaman lain yang lebih utuh.

Dekonstruksi mengajarkan saya untuk tidak cepat puas, apa-apa yang sudah saya raih (puncak), berani mendekonstruksi lagi, agar saya senantiasa mendapatkan pemahaman kemungkinan-kemungkinan yang lain secara utuh, karena dekonstruksi tak berawal dan tak berakhir, artinya tak henti dan terus berkreasi. Hal ini sejalan apa yang dikatakan M. Dwi Marianto, dan juga sebagai pemicu saya dalam provokasi penciptaan karya seni. 
Kreativitas, inovasi dan kebaruan hanya bisa diraih dinyatakan oleh orang yang percaya akan misteri dan kekuatan tersembunyi di balik yang tidak kelihatan, dan mampu melihat potensi dari relasinya dengan lingkungan (alam, sosial, dan spiritual). Selain itu ia harus berani melawan badai sinisisme dan skeptisisme yang mungkin datang dari dalam diri atau pun dari luar dirinya.

Seniman yang baik juga harus demikian. Ia harus percaya pula dengan media yang digeluti, mengenali dunia kreatifnya, dan meyakini bahwa dalam dunia kerjanya itu ada ruang. Semakin didekati dan diselami ruang itu akan membukakan ruang-ruang lain, dan seterusnya. Dalam ruang-ruang yang akan terbuka itu berkeliaranlah tanda-tanda kebijaksanaan dan tanda-tanda potensi untuk dipetik, dibawa keluar, dan dinyatakan jadi karya apa saja.

Nampaknya Hening Swasono telah mulai mengenali kekuatan dari potensi-potensi tersembunyi itu. Ia menyadari bahwa dalam keheningan swasana itu ada suara, nada, rupa, dan dinamika maya, karyanya yang sekarang adalah anyaman dari berbagai hal yang tadinya maya itu jadi nyata (Marianto, 2006).

Kata atau "teks" tersebut di atas menguatkan saya untuk berkreasi lebih optimis dan kreatif, juga sekaligus provokasi karya, untuk lebih berani menembus tantangan realitas yang selalu berubah-ubah. Sehingga lahirlah karya apa saja, membebaskan imajinasi dan interpretasi/ tafsir penikmat seni, semakin banyak tafsir, itulah harapan saya agar peran aktif penikmat, baik yang positif maupun negatif, saling memberikan kontribusinya, sehingga fungsi sosial seni hidup dan berkembang.

\section{Penutup}

\section{Kesimpulan}

Melalui dekonstruksi diri sendiri, potensi diri dan imajinasi terbuka lebar-lebar hamparan penciptaan karya seni tak berujung dan tak berakhir luas membentang seolah membukakan kelegaan untuk berkreasi, bermain dan beropini dari sinilah lahir karya dengan segala kemungkinan-kemungkinan baru yang selama ini tidak dapat dimungkinkan, keliaran dan kegilaan mengalir deras begitu saja, seolah tak dapat dihentikan, tapi sesungguhnya dapat dihentikan sejenak yaitu dengan menunda puncak kreasi untuk dikaji ulang, setelah itu didekonstruksi lagi, begitu seterusnya, agar dinamika dunia dekonstruksi tetap hidup dan berkembang dekonstruktor-dekonstruktor yang lainnya. Perihal ini saya rasakan sendiri keberanian untuk menyatakan apa-apa yang saya kreasikan dalam bentuk seni apa saja.

Hal-hal yang menunjang, sarana studi luas dan peralatan komplit, dan yang paling utama keluarga (anak dan istri) mendukung. Selain itu pada penciptaan karya sebelumnya memang sudah terbiasa dalam mengengerjakan dengan bahan-bahan seperti pada penciptaan sekarang.
Hal-hal yang menghambat, ada tamu tiba-tiba, juga faktor kesehatan. Selain itu memang buku-buku terasa sangat sulit didapatkan karena belum mengetahui pasti perpustakaan mana yang banyak tersedia buku-buku penunjang konsep penciptaan sekarang ini.

\section{Saran-saran}

Hambatan laten untuk penciptaan seni, karena kerja otak kanan untuk seni, otak kiri untuk rasio, di kala berkarya seni baru mencapai puncak-puncaknya, tiba harus menulis tesis, apa yang tejadi kelelahan otak yang tak menentu, mengurangi yang berimbas pada beban psikologis. Untuk memperkecil hambatan tersebut di atas, paling tidak pandai-pandai mensiasati waktu, saya akui hal ini sangat sulit untuk keduanya jalan seiring, dan semuanya maksimal, pasti ada salah satu yang diprioritaskan.

Pada proses penyusunan konsep penciptaan kadang memang terjadi kajian yang interdispliner (menggabungkan banyak pendekatan), hal ini perlu kematangan penguasaan keilmuan lain, minimal menguasai epistomologi atau filsafat ilmu sehingga persoalan pendukung konsep secara teoritis dapat tersusun dengan jelas induk keilmuannya. Untuk masa mendatang diharapkan ada mata kuliah yang dapat mendukung kerja-kerja penciptaan semisal: Filsafat Ilmu Pengetahuan.

Metode penciptaan sebuah karya tentunya dengan sendirinya dapat berkembang tanpa harus seragam dengan dukungan mata kuliah yang berdasar kajian interdisplin.

\section{Daftar Pustaka}

Awuy, Tommy F. (2002), Identitas Terbagi dalam Seni Rupa Kontemporer. Yayasan Seni Cemeti, Yogyakarta.

Barthes, Roland. (1977), "The Death of the Author" dalam Image Music-Text, Fontana.

Bennington, G. \& J. Derrida. (1981), Jacques Derrida. Diterjemahkan oleh George Bennington. The University of Chicago Press, Chicago.

Brian, Wallis. (1984), Art After Modernism : Rethinking Representation The New Museum of Contemporary Art, New York.

Burhan, M. Agus. (1996), Simbol-simbol Tradisi dalam Jiwa Kontemporer. dalam katalog Cracks Painting of Hening Swasono, The Financial Club Grha Niaga Jakarta.

Calne, Donald B. (2004), Batas Natar; Rasionalitas dan Perilaku Manusia, terjemahan Para kitri T. Simbolan. Kepustakan Populer Gramedia, Jakarta.

Collins, J. dan B. Mayblin. (2001), Introducing Derrida. Icon Books Ltd, Cambridge. 
Derrida, J. (1967), De la GrammatologieI. Les Edition de Minuit, Paris. (1981), "The Double Session" dalam Dissemination. The Athlone Press, London.

-, (1981), Positions. Terjemahan dan kata pengantar oleh Hlan Bass. The University of Chicago Press, Chicago.

Deschamps, C. (2003), Quarante ans de philosophie en France: La Pensée singulière. De Sartre à Deleuze. Bordas, Paris.

Inada, K.K. (1970), Nagarjuna: A Tranlastion of this Mulamadhyamakakarika with an Introductory Essay, The Hokuseido Press, Tokyo.

Kajiyama, Y. (1993), "Madhyamika", dalam M. Eliade (ed.). The Encyclopedia of Religion Volume 9. MacMillan Publishing Company, New York.

Kearney. (1972), The Psychology of Imagination. Citadel Press, New York.

Marianto, M. Dwi. (2006), Dibalik Keheningan Swasono; dalam Katalog Pameran instalasi, Merayakan Seni Visual Kontemporer dan Bangkitnya Perupa, PPS ISI Yogyakarta.

(1994), "Berbagai Fenomena Seni dan Bingkai Pandang terhadap Seni Kontemporer" dalam SENI, Jurnal Pengetahuan dan Penciptaan Seni, IV/01- Januari 1994. Yogyakarta : BP ISI Yogyakarta. (1996), Retak-retak Bahasa Hening: dalam katalog Cracks Painting of Hening Swasono, The Financial Club Grha Niaga Jakarta.

Murti, T.R.V. (1968), The Central Philosophy of Buddhism: A Study of the Madhyamika System. London: George Allen and Unwin Ltd.

Nagarjuna, (1951), Vigrahavyavartani $(V V)$ versi E. H. Johnston \& Arnold Kunst (eds.), MCB, IX, Juli,. The Hokuseido Press, Tokyo.

Oliveira, de Nicolas et.al (1998), Installation art, Thames and Hudson, London.

Rice, P. \& Waugh, P.(ed.). (1996), Modern Literary Theory : A Reader, Third Edition, Arnold, A member of the Hodder Headline Group, London.

Streng, F.J. (1993), "Nagarjuna", dalam Mircea Eliade (ed.), The Encyclopedia of Religion Volume 10. McMillan Publishing Company, New York.

Subroto Sm. (April 2004), Mengubah "Kebetulan"Menjadi "Kebenaran", dalam ARS, Jurnal Seni Rupa dan Desain, Nomor: 01, Yogyakarta FSR ISI Yogyakarta.

Ward, G. (2003), Teach Yourself Postmodernism, Hodder \& Stoughton Ltd, London.

Zaelani, Rizki A. (2002), Personal atas Nama High Art, Yayasan Seni Cemeti, Yogyakarta.

Zimmer, H. (1959), Philosophies of India, Joseph Campbell (ed.). Meridian Book, Inc, New York.

\section{Lampiran : Tema "Re-konstruksi (yang) Tersingkirkan"}

Penataan ulang dalam arti pemahaman yang sudah bergeser bagi mereka yang termarjinalkan, berusaha bangkit dari puing budaya yang sudah rapuh, keropok, aus, retak-retak, pecah-pecah, belah-belah, tinggal menunggu waktu runtuh dan menimpanya.

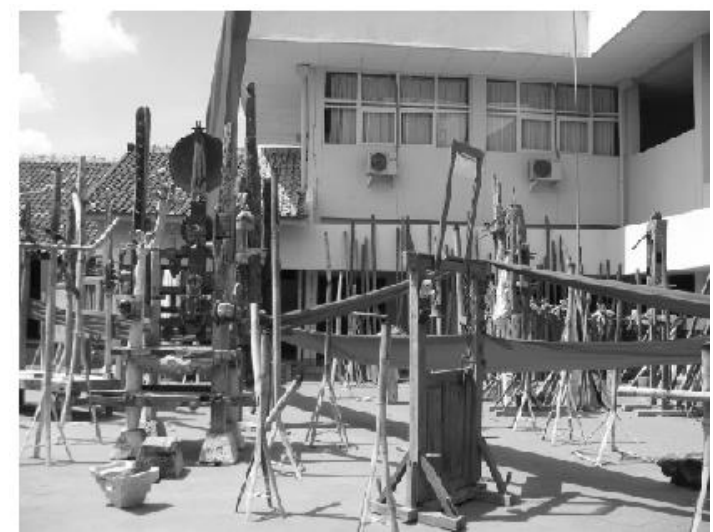

Gambar 1 "Rekonstruksi yang Tersingkirkan"

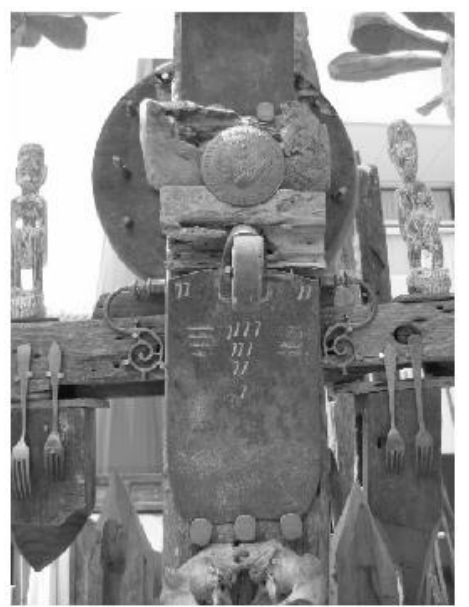

Gambar 2 Detail "alih fungsi, benda pakai menjadi elemen karya" 
, Vol.5, No. 2, Agustus 2007 : 133 - 160

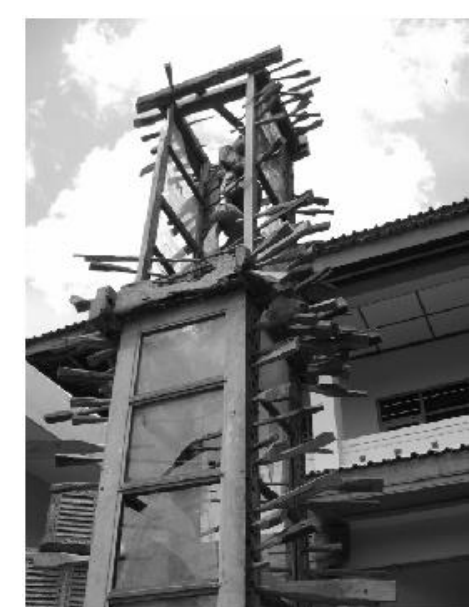

Gambar 3 Daun pintu dan penerapan pasak sebagai garis yang mengisi dan mengikat.

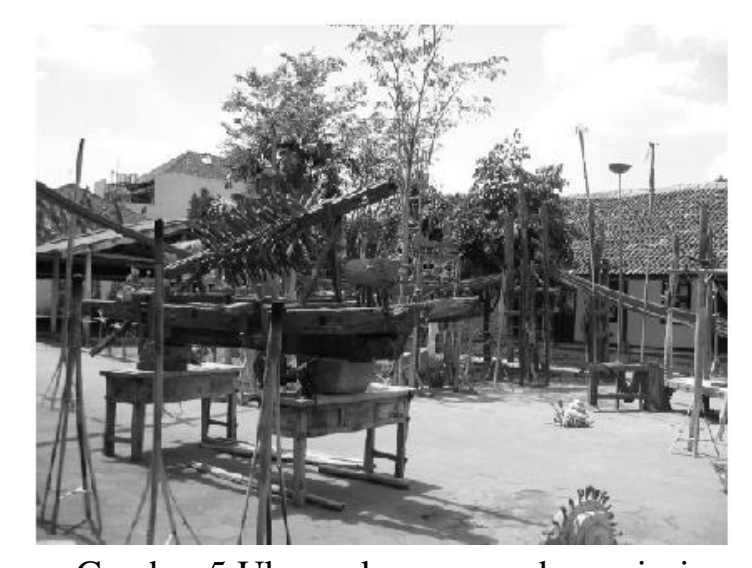

Gambar 5 Ukuran karya yang bervariasi 